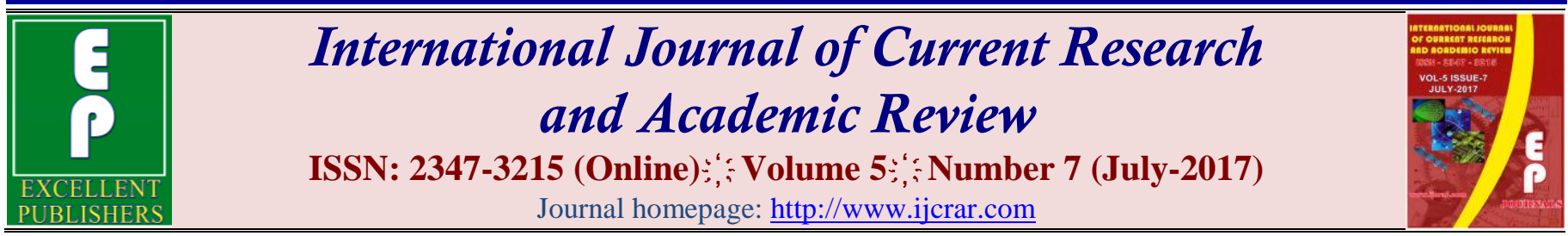

doi: https://doi.org/10.20546/ijcrar.2017.507.005

\title{
Pilomatrixoma in the Parotid Region- A Case Report
}

\author{
Meena Patil ${ }^{1^{*}}$ and Ravi Swami ${ }^{2}$

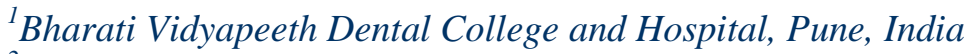 \\ ${ }^{2}$ Bharati Vidyapeeth Medical College, Pune, India \\ *Corresponding author
}

\begin{abstract}
Pilomatrixoma is a relatively benign cutaneous adnexal neoplasm with differentiation towards the matrix and inner sheath of a normal hair follicle as well as hair cortex. ${ }^{(1)}$ It is commonly seen in head \& neck region. We present a case of 49 year old female presenting with a swelling in the preauricular region. She was referred for Fine needle Aspiration Cytology (FNAC). On aspiration smears showed picture of benign salivary gland neoplasm. However histopathological diagnosis was pilomatrixoma.
\end{abstract}

\section{Article Info}

Accepted: 02 July 2017

Available Online: 20 July 2017

\section{Keywords}

Fine needle aspiration cytology, Pilomatrixoma, Salivary gland.

\section{Introduction}

Pilomatrixoma, also known as calcyfying epithelioma of Malharbe, is a slow-growing benign cutaneous adnexal neoplasm. It was first described by Malharbe and Chenantois in 1880. It was in 1961 that Forbes and Helwing suggested the name Pilomatrixoma. ${ }^{(2)}$

Pilomatrixoma accounts for upto $0.2 \%$ of all routine dermatopathologic specimens. The tumor occurs in all age groups. About $30-50 \%$ of cases present in young individuals less than $30 \mathrm{yrs}$ of age. Previous studies have shown a female predominance. ${ }^{(1)}$

Pilomatrixoma favour hair bearing areas with majority of cases arising in the head and neck region as well as upper extremities. Patient present with solitary, asymptomatic, slowly growing cystic or firm nodule $0.5-3 \mathrm{~cm}$ in diameter. $^{(1)}$

In this report we present a case of pilomatrixoma localized in preauricular area (Parotid region).

\section{Case report}

A $49 \mathrm{yr}$ old female patient presented with complaints of swelling in the preauricular region. The swelling was a small painless nodule about $1.5 \mathrm{X} 1 \mathrm{~cm}$ slowly growing since 3 months. She was referred for fine needle aspiration cytology with clinical diagnosis suspicious of salivary gland neoplasm. Aspiration smears showed cohesive clusters of benign epithelial cells. Diagnosis offered was benign salivary gland neoplasm. The nodule was operated and biopsy sent for histopathological confirmation. On histopathology, sections showed densely cohesive basaloid cells and anucleate squamous cells (Ghost cells) in clusters along with multinucleate giant cells and areas of calcification. These features were suggestive of benign tumor of cutaneous appendages with differentiation towards hair follicle called as Pilomatrixoma.

Pilomatrixoma or Calcifying epithelioma of Malharbe, is a benign skin neoplasm that arises from hair follicle matrix cells. In 1880, Malharbe and Chenantais first described this lesion referred to as the calcifying 
epithelioma. ${ }^{(3)}$ The term pilomatrixoma was introduced in a publication by Forbisand Helwing in 1961 to better convey the histologic course. ${ }^{(4)}$

It may be seen in any age group, mostly occurring in children or in the first two decades of life. It usually arises in the head and neck region. ${ }^{(5)}$ Pilomatrixoma clinically presents as a slow-growing, solitary, firm, well-circumscribed, painless dermal or subcutaneous tumor. ${ }^{(6)}$ Histopathological examination is highly useful in the diagnosis of pilomatrixoma since the clinical diagnosis of pilomatrixoma is difficult. Histopathological examination reveals round islets of epithelial cells surrounded by a connective tissue capsule. In these islets, the eosinophilic ghost cells that have lost their nuclei are the specific indicators of pilomatrixoma. In addition to these islets, there are foreign body giant cells and basaloid cells with prominent nucleoli. Calcification is seen in $70-85 \%$ of the cases. The differential diagnosis of pilomatrixoma should include epidermoid cyst, foreign body granuloma, dermatofibroma, keratoacanthoma, nodular subepidermal fibrosis, basal cell carcinoma, osteoma and skin metastasis. $^{(7)}$

Fig.1 FNAC- Clusters of epithelial cells

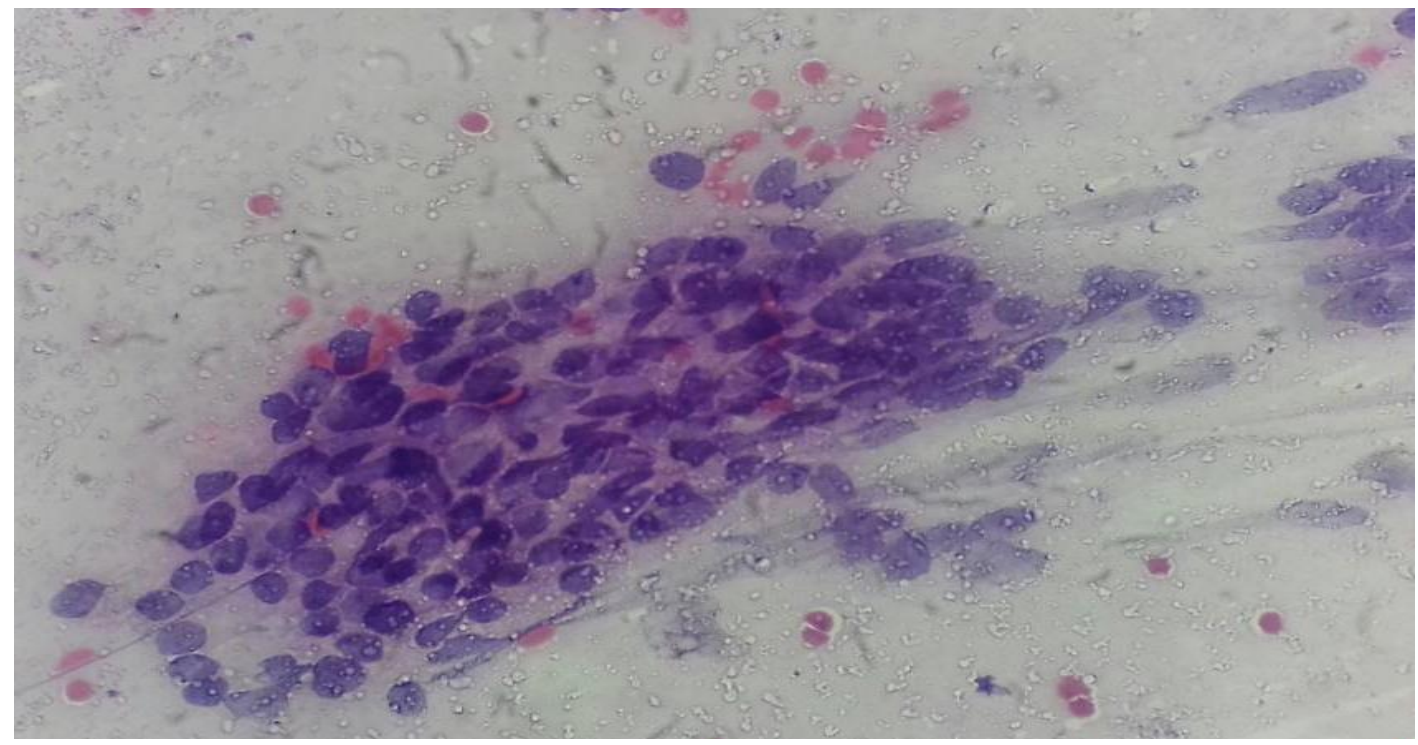

Fig.2 FNAC- Clusters of epithelial cells

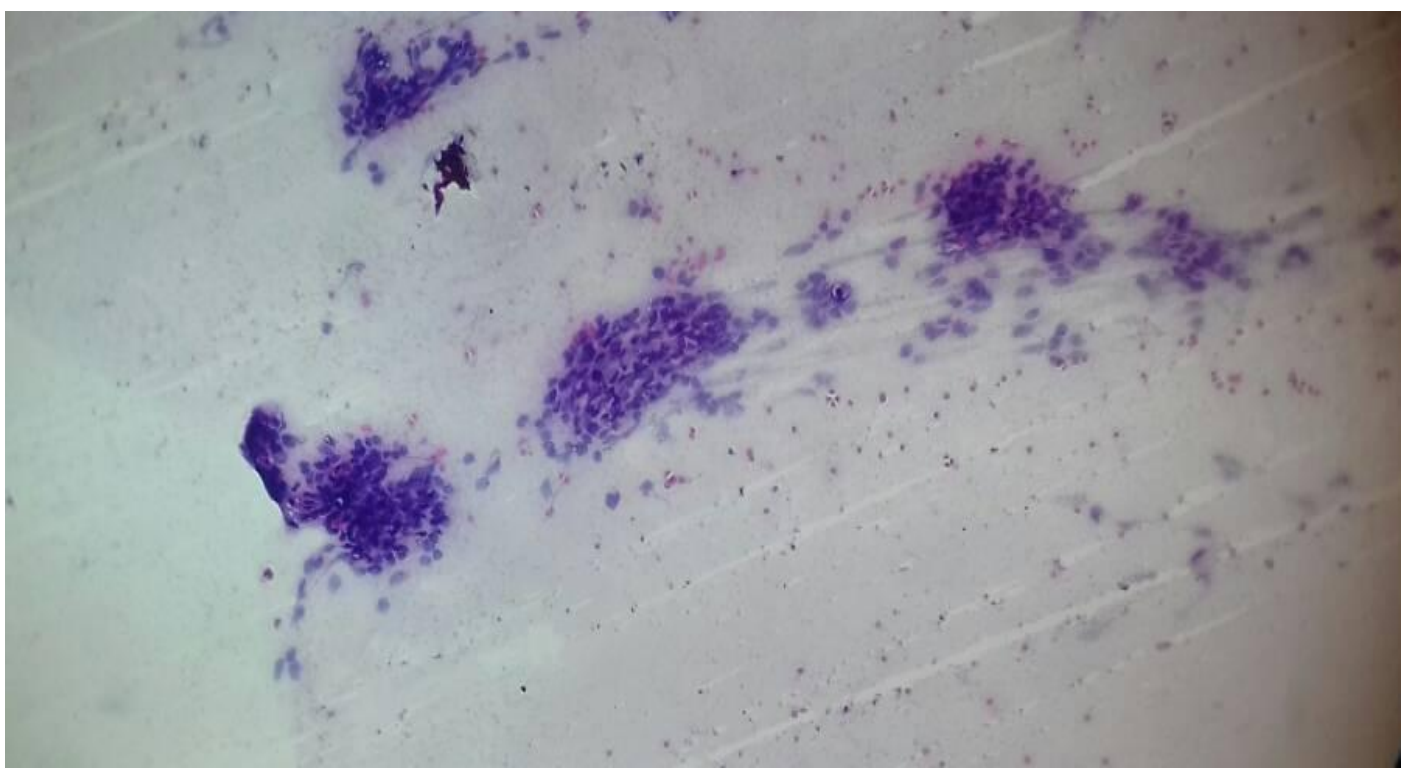


Fig.3 HP. X400- Ghost cells with giant cell

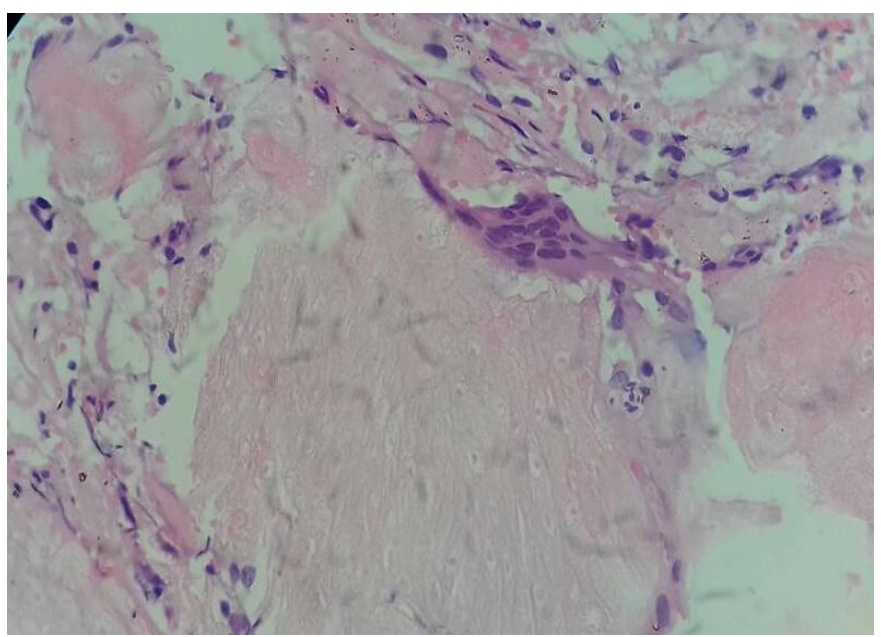

Fig.4 HP. X400- Ghost cells with giant cell

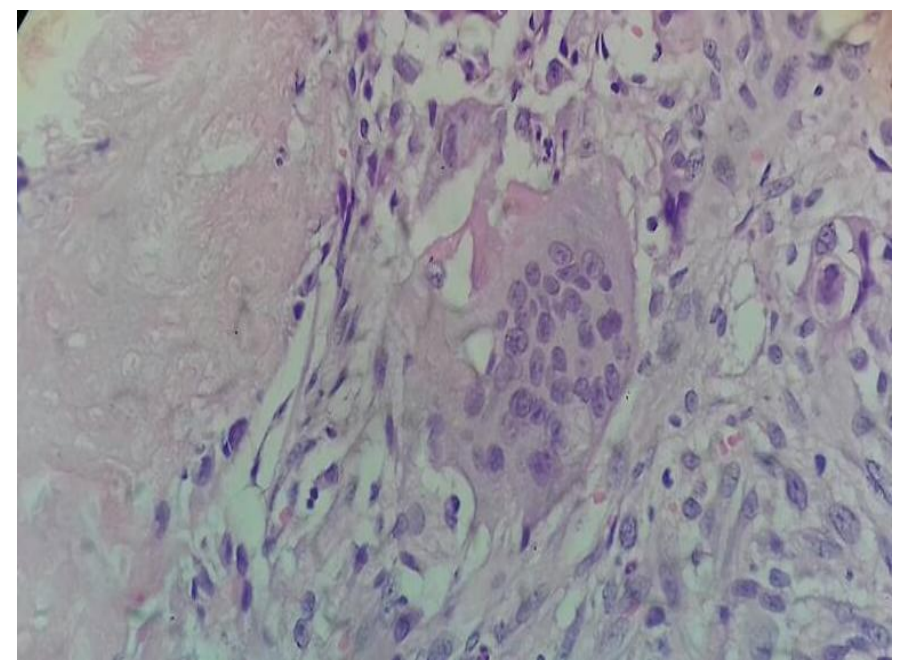

Fig.5 HP.X400- Gost cells with calcification

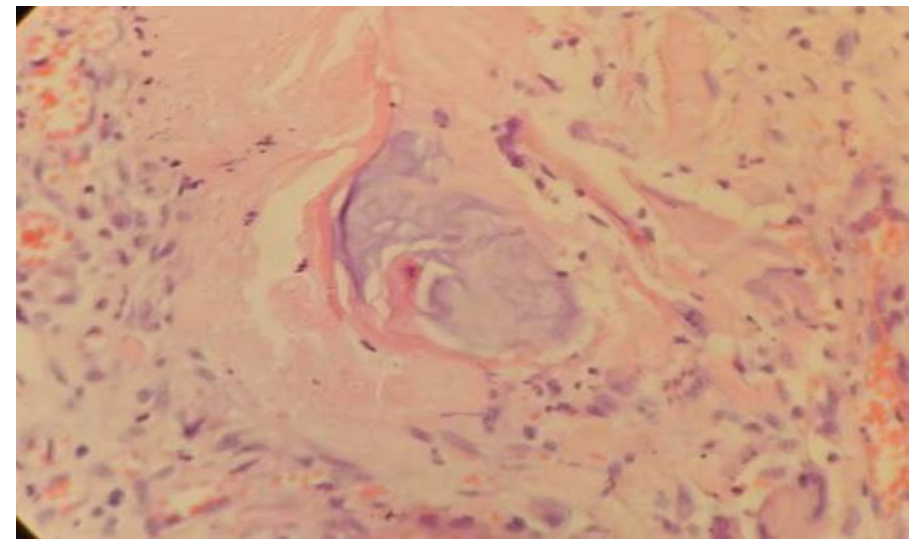

Likewise on cytology, one can expect a varied cytomorphological spectrum depending on the stage of growth. Because of this varied presentation many authors have misdiagnosed pilomatrixomas on cytology. On 
cytological overview of literature we found that pilomatrixomas on FNAC were diagnosed as malignant lesions. ${ }^{(8)}$ Similarly in our case, because of presence of cellular clusters of epithelial cells, absence of ghost cells, giant cells and calcification on cytology, location of lesion, we thought of benign salivary gland neoplasm of parotid gland; as these features better seen on histopathology.

Likewise, Luciano et al., in his case report has mentioned that, pilomatrixoma was misdiagnosed on cytology as mucoeoidermoid carcinoma because of the basaloid cells of pilomatrixoma were mistaken as intermediate cells of mucoepidermoid carcinoma. ${ }^{(10)}$ Shivkumar S et al., also had diagnostic difficulty on fine needle aspiration which led to the three differential diagnosis of mucoepidermoid carcinoma, squamous cell carcinoma and calcifying odontogenic tumor. ${ }^{(11)}$

In this reported case, the definitive diagnosis was made after histologic examination following excision of the mass.

Surgical excision is the method of choice in the treatment of pilomatrixoma since pilomatrixoma is benign lesion and dose not regress spontaneously. Postoperative recurrence of pilomatrixoma is extremely rare and occurs in $0-3 \%$ of the cases. ${ }^{(7)}$

Pilomatrixoma should be kept in mind in the differential diagnosis of head and neck tumors. The cytologic appearance can be misleading \& hence excision with subsequent histopathologic examination will lead to the correct diagnosis.

\section{Acknowledgement}

We are very thankful to Dr. Shilpa Patel-Fernandis, V care Laboratory, Sinhgad Road, Pune for her support.

\section{References}

Agarwal RP, Handler SD, Mathews MR, Carpentieri D. Pilomatrixoma of the head and neck in children. Otolaryngeal Head Neck Surg.2001 Nov; 125(5):510-5.

Brandner MD, Bunkis J. Pilomatrixoma presenting as a parotid mass. Plast Reconstr Surg. 1986 Oct; 78(4):518-21.

Forbis R, Helwig EB. Pilomatrixoma. Arch Dermatol. 1961; 83:606-618.

MacDonald L, Yazdi HM. Nondiagnostic fine needle aspiration biopsy of the tyroid gland: a diagnostic dilemma. Acta Cytol. 1996 May-June; 40(3):4238. [PubMed]

Malherbe A, Chenantais J. Note sur1' pithomecalcifi des glandes sebacees. Prog Med (Paris). 1880; 8:826828.

Moehlenbeck FW. Pilomatrixoma (calcifying epithelioma). A stastical study. Arch Dermatol. 1973 Oct; 108(4):532-4.

Preethi TR, Jayashree K, Abraham EK. A case of pilomatrixoma misdiagnosed as metastatic carcinoma on fine needle aspiration cytology. J Cytol 2007; 2494):207-8. [PubMed]

Roche NA, Monstrey SJ, Matton GE. Pilomatricoma in children: common but often misdiagnosed. Acta Chir Belg. 2010 Mar-Apr; 110(2):250-4. [PubMed]

Sivakumar S. Pilomatrixoma as a diagnostic pitfall in fine aspiration cytology: a case report. Acta Cytol. 2007 Jul-Aug; 5194):583-5. [PubMed]

Wells $\mathrm{Nj}$, Blair GK, Magee JF, Whiteman DM. Pilomatrixoma: a common, benign childhood skin tumor. Can J Surg. 1994 Dec; 37(6):483-6.

WHO classification of tumors, Pathology and Genetics of Skin tumors Benign tumors of follicular differentiation, by Philip E. LeBoit, Günter Burg, David Weedon, Alain Sarasin; IARC Press, Lyon 2006. Pp. 153.

\section{How to cite this article:}

Meena Patil and Ravi Swami. 2017. Pilomatrixoma in the Parotid Region- A Case Report. Int.J.Curr.Res.Aca.Rev. 5(7), 28-31. doi: https://doi.org/10.20546/ijcrar.2017.507.005 